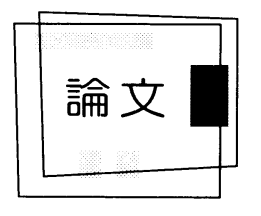

\title{
超音波ホモジナイザ高周波電源の開発と 水乳化燃料の生成*
}

\author{
木 船 弘 康** 畑 中義 博**
}

Development of the High Frequency Power Supply for Ultrasonic Homogenizer and Generation of Emulsified Fuel Oil with Water

By Kifune Hiroyasu, Hatanaka Yoshihiro

A novel zero current switching high frequency inverter as a power supply for the high-intensity ultrasonic homogenizer was developed to realize the high cost performance and stable operation in wide range of load. In this paper the procedure of the circuit design was described on the basis of numerical analysis with respect to the distortion factor of output voltage, power factor and switching stresses. Furthermore, the emulsified fuel oil with water by using high-intensity ultrasonic homogenizer was generated and estimated.

\section{1. まえがき}

1997年9月にIMOの海洋污染防止条約国会議で 海洋污染防止条約 (MARPOL73/78) に船舶から の大気污染防止に関する追加の議定書が採択され， 舶用ディーゼルエンジンからのNOx排出に関する テクニカルコードも同時に採択された。そして 2000 年1月より条約が発効している。NOxの低減 技術の一つとして水乳化燃料の利用があり、水乳 化燃料の一部実用化がなされるなかで，本研究で は水乳化燃料の生成に強力超音波を利用すること を提案している。

強力超音波を発生する超音波ホモジナザは高周 波駆動であるため, スイッチング電源が多く用いられ る.一般的にスイッチング電源は高周波駆動に起因 するノイズやスイッチング損失発生等の問題を抱えて おり, 特に近年における電子機器の広範な利用から, 装置外部にノイズを発生させないという観点, EMI (Electro Magnetic Interference) の抑制が電源機器に

*原稿受付 平成 13 年 1 月 31 日

**正会員 東京商船大学（江東区越中島2-1-6）
も求められている。これに対して筆者の一人は既 にソフトスイッチング技術を用いた高周波電源回 路を提案しており，その有効性を確認している(1)(2). 本研究ではスイッチング素子減少によるローコス 卜化及び電力変換効率の向上, さらには超音波木 モジナイザの安定動作を目的に新たに二石型ZCS (Zero Current Switching) 高周波インバータを開 発した。

水乳化燃料の生成においては, 長谷川が指摘し ているように(3)，乳化燃料の生成に当たって，コス トの削減という観点から乳化㓮の添加量をできる だけ少なくすべきである。強力超音波により生成 した水乳化燃料では微粒化された水粒子が然料油 中に均一に分散し, 安定性を持つ傾向がある。こ の性質を利用して本研究では開発した高周波電源 の駆動により，乳化剂を用いずに安定な乳化燃料 を得るための実験を行い，その特性を評価検討し ている。

\section{2. 高周波インバータ}

本章では超音波ホモジナイザ高周波電源としての 高周波インバータ回路の開発経緯と今回提案する新 
しい回路の特徴とその回路設計について述べる.

\section{1 超音波ホモジナイザ用電源回路 高周} 波スイッチング動作に起因するサージ電圧やサー ジ電流の発生，およびこれらによるノイズの発生 やスイッチング損失の増大など，高周波インバー タにはいくつかの共通した問題がある。特に超音 波ホモジナイザの電歪型ボルト締めランジュバン 振動子は回路の先鋭度が極めて高いため, わずか な周波数の動き，振動面への圧力の変化などによ って等価回路定数が大きく変化する。こうした負 荷に対応すべく，これまで数種の高周波インバー 名，(4) (8) 開発してきた。また従来，超音波ホモ ジナイザを高出力化するために電力半導体（スイ ッチ）の素子数を增やし，スイッチ一つあたりの 出力電力を小さくする等してスイッチにかかる負 担の低減を行ったが，結果的にインバータ回路が 大型化し，コスト増にもなった(1)(6). また高出力化 に伴って高い出力電圧が要求されるため, インバ 一タ回路の出力端子にトランスを設けたが，イン バータの出力電圧中に直流成分 ${ }^{(8)}$ が含まれこれに よりトランスが直流偏磁するといった問題も浮上 してきた。そこで高い電力供給を実現しながらト ランスの直流偏磁問題を解決し，かつインバータ の高周波駆動に起因する問題を改善する新たなイ ンバータ回路の開発が必要となった。本稿で提案 する超音波ホモジナイザ用高周波電源は図1に示す 新 2 石型SEPP (Single Ended Push Pull) $\cdot$ ZCS高 周波インバータ回路である。このインバータ回路 では電源装置の高周波化に伴う諸問題を解決する ソフトスイッチング技術の一手法としてのZCS動 作を採用している.

本回路ではこのZCS動作を実現するために，リ
アクトル（L1,L2）を接続することでスイッチやダ イオードに流れる電流に連続性を持たせている. 理論上，リアクトルはエネルギーを消費しないが, 実回路上に打いては銅損が発生するためインバー タの電力変換効率が低下してしまう。そこでリア クトルでの銅損発生を極力抑えるために， L1,L2を 主スイッチに逆並列接続されるダイオードに対し直列 に接続している点が本回路の大きな特徴となってい る.なお, 超音波ホモジナイザの機械的共振周波数 が約 $19[\mathrm{kHz}]$ であることから,この周波数帯に適する 電力半導体スイッチング素子として IGBT (Insulated Gate Bipolar Transistor: 2MBI50N-060,富士電機 製)を主スイッチとして用いた。また, SEPP型となっ たことでIGBTやダイオード等の素子点数が減り, 上 り小型化が可能となった。一方このことで出力電压 中に直流成分が発生し, 出力トランスの直流偏磁 が発生するという問題が生じたため，キャパシタ ンスCsをL3に対し直列に接続した。これにより交 流成分のみを出力トランスに供給することが可能 となった。

2. 2 負荷等価回路 図2は超音波振動子系の 負荷等価回路を示している。(a)のCdは制動容量, $\mathrm{Rm}$ は負荷抵抗， $\mathrm{Lm}$ と $\mathrm{Cm}$ はリアクタンス成分であ る。超音波振動子系が完全に共振状態の時 Lmと $\mathrm{Cm}$ は相殺されるため, 負荷等価回路は $\mathrm{Rm}$ と $\mathrm{Cd}$ の 単純な並列回路として表すことができ, 回路解析 する上でも素子数が減るため計算が容易である. しかし，電源回路を設計する上で超音波振動子が 共振状態をわずかにはずれた状態または完全には ずれた状態も把握しておくことが重要である。そ こで計算を簡易化した上で超音波振動子の状態を 広い範囲で計算するため, 図 $2(\mathrm{a})$ の合成アドミタ

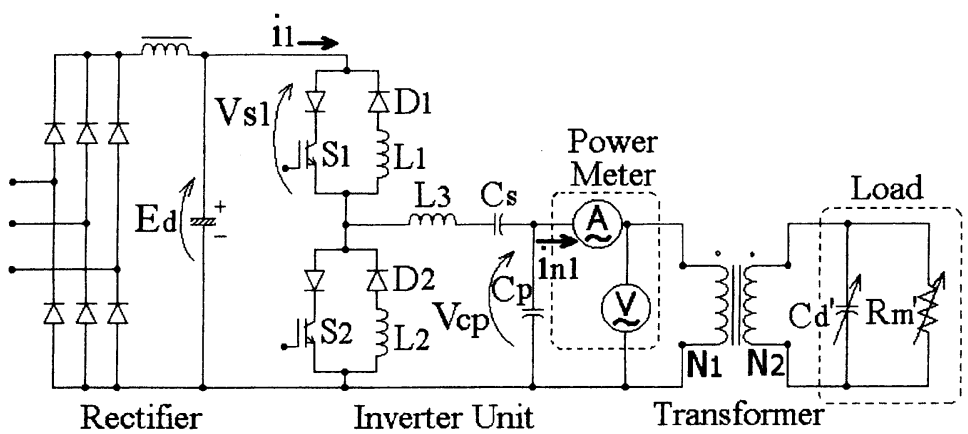

図12石型SEPP ZCS高周波インバータ 


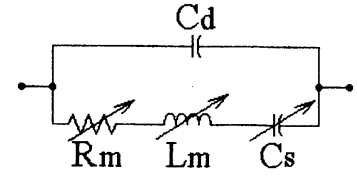

(a)一般的表現による等価回路

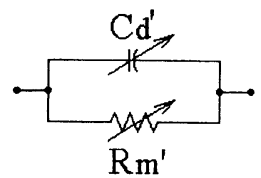

（b)簡易化した等価回路

\section{図2 超音波振動子系の等価回路}

ンスベクトルの式を実数部 Re $[\mathrm{Y}]$ と虚数部 $\operatorname{Im}[\mathrm{Y}]$ に 分け(式1)，実数部を見かけの負荷抵抗Rm'，虚数 部を見かけの制動容量 Cd'として定義する（図2

(b) ,式2)。実験值から算出される值はこのRm'と Cd'であり, ディジタルパワーメータの指示值 Vcp[V], In1[A], Po[W]をもとにして計算する(式3).

2. 3 インバータ回路の特性解析 インバー タでは回路を構成する要素（回路素子）の大きさ により回路自体の性質が変わり, それらの值の大 小によりZCS動作の可否も決まる。したがって回 路素子の值を決める場合，その大小による特性の 変化を把握しておくことが重要となる。そこで, インバータ回路の設計を行う前段階として回路諸 特性の数值解析を行った. 回路解析にはいくつか の手法があるが, 本研究では無次元化パラメータ を用いた回路の状態方程式(付録)を導き，これを4次 ルンゲクッタ法で数值計算した。具体的にはイン バータ回路中の各回路素子の大きさの比（例：リ アクトルの比 $\mathrm{L} 1 / \mathrm{L} 3$ 等) や回路中の各部電圧と電源 電压との比 (例： $\mathrm{Cp}$ の無次元化電圧 $\mathrm{Vcp}{ }^{*}=\mathrm{Vcp} / \mathrm{Ed}$ ) を無次元化パラメータとしてとり, 回路素子の大 小関係においてZCS動作の可否を調べた。無次元 化パラメータの詳細は表1に示す通りである. 本研 究で用いた超音波ホモジナイザの出力が最大とな る共振周波数は $19[\mathrm{kHz}]$ 付近であり, 出力電力を 700～800[W]程度としたとき超音波ホモジナイザ の等価回路定数は, Rm' $=390 \sim 450[\Omega], \mathrm{Cd}^{\prime}=0.025 \sim$ $0.035[\mu \mathrm{F}]$ の範囲にある。筆者らの実回路設計上の 経験から, 回路構成要素であるキャパシタンス （Cs, Cp）の大きさが回路動作に与える影響は大

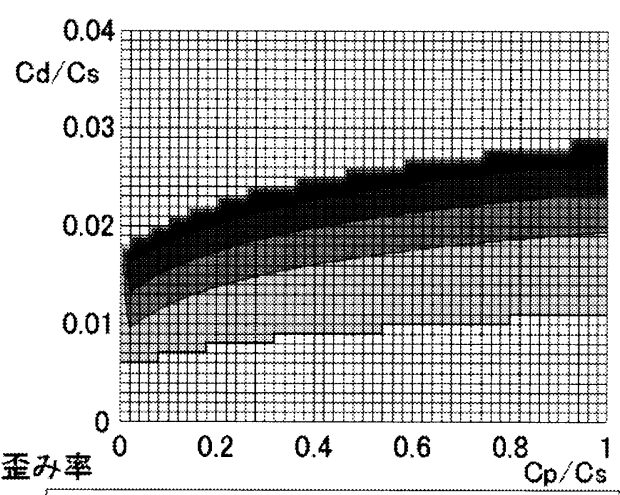

Jnon-ZCS 0-0.1 0.1-0.2=0.2-0.3=0.3-0.4

\section{図3 出力電圧の歪み率}

$$
\begin{aligned}
& \mathrm{Y}=\frac{\mathrm{Rm}}{\mathrm{K}}+j \frac{\omega \mathrm{Cd} \cdot \mathrm{K}-\omega \mathrm{Ls}+\frac{1}{\omega \mathrm{Cs}}}{\mathrm{K}} \\
& \text { ただし } \mathrm{K}=\mathrm{Rm}{ }^{2}+\left(\omega \mathrm{Ls}-\frac{1}{\omega \mathrm{Cs}}\right)^{2} \\
& \omega=2 \pi \text { fo } \\
& \mathrm{Rm}^{\prime}=\frac{1}{\mathrm{Y} \cos \theta}[\Omega] \quad \mathrm{Cd}^{\prime}=\frac{\mathrm{Y} \sin \theta}{\omega}[\mathrm{F}]
\end{aligned}
$$

n は出力トランスの一時側と二次側の巻き数比

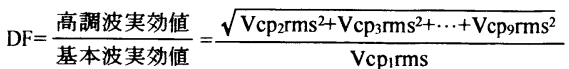

$$
\begin{aligned}
& \text { ただし } V_{c p_{k} r m s}=\sqrt{\frac{a_{k}^{2}+b_{k}^{2}}{2}} \quad(k=1,2,3, \cdots, 9) \\
& a_{k}=\int_{0}^{1} V c p^{*}(z) \cdot \cos (2 \pi n z) \quad b_{k}=\int_{0}^{1} V c p^{*}(z) \cdot \sin (2 \pi n z)
\end{aligned}
$$

きい。そこで，各キャパシタンス（Cd', Cp, Cs) をCsにより無次元化し, キャパシタンス比として $\alpha=\mathrm{Cp} / \mathrm{Cs}, \beta=\mathrm{Cd} / \mathrm{Cs}$ 定義し，これを一定間隔 で変えたときにインバータ回路がZCS動作できる かどうかを数值解析により調べた.

\section{4 ZCS動作領域と諸特性 図 $3 ， 4,6,7$} は $\mathrm{Cp} / \mathrm{Cs} と \mathrm{Cd} / \mathrm{Cs}$ の值をそれぞれx軸とy軸にとっ た平面内にインバータ回路のZCS動作の可否を表 したものであり，計算条件として抵抗比 $\mathrm{R} / Z$ Z一 定としている。 ハッチングした領域はインバータ 回路のZCS動作が可能となるZCS動作領域を表し 


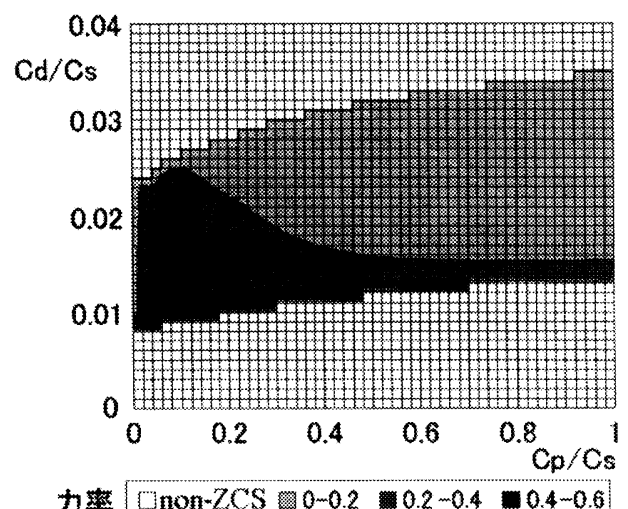

図4 力率

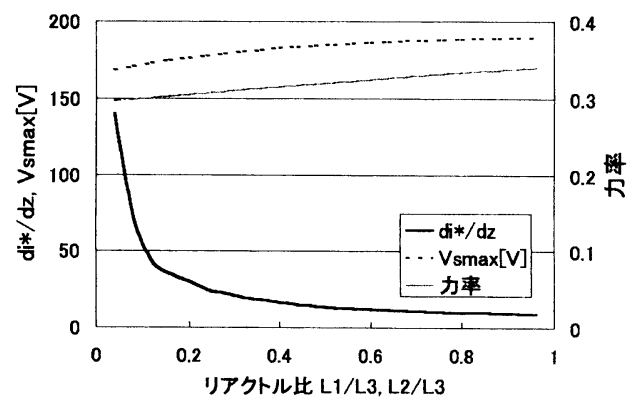

図5 リアクトル比の影響

ており，ハッチングしていない部分は非ZCS動作 領域を表している。したがってこのZCS動作領域 内のいずれかの点で回路設計を行う場合，インバ 一タ回路のZCS動作が実現される.

図3においてZCS動作領域内で等高線により表さ れているのは出力トランスを理想トランスとして 考えた場合のインバータ部出力電压 $V \mathrm{cp}$ の波形の歪 み率である，歪み率 (DF:distortion factor) の計 算は各解析条件に打いて基本波から第 9 高調波まで の実効值を算出し，式4によりその大きさを求め た.またこれ以上の高次の高調波成分の計算を行 う場合, 計算精度の高度化が要求され, 結果的に 計算量が膨大となる。しかし実際はこうした高次 の高調波が含まれる割合ははわずかであり，歪み 率の計算に大きな䛊差を与えるものではないため, 解析範囲を第9高調波までとした。超音波振動子は その機械共振の先鋭度がきわめて高いため, 共振 周波数付近での動作は狭帯域の機械フィルタとし て見なされる(9).このためインバータが出力する電

\section{表1 無次元化パラメータ}

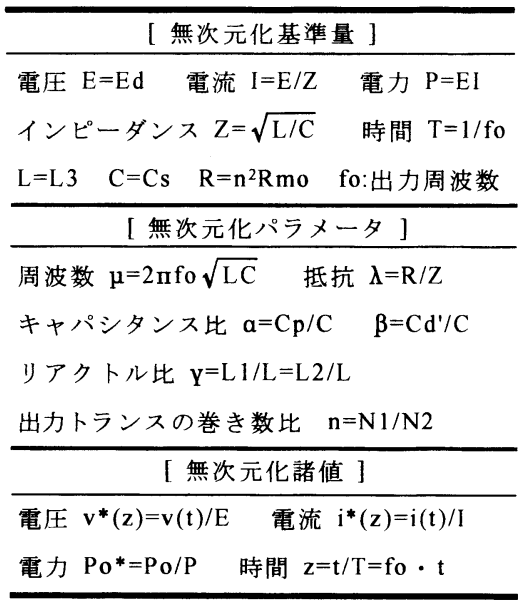

圧のうち，振動子に供給されるのは基本波成分の みであり，高調波成分のエネルギーは利用されな い.このことから効率よく電気エネルギーを振動 子に供給するためには，インバータが出力する電 圧波形の歪みを小さくすることが望ましい。した がって図3より $\mathrm{Cd} / \mathrm{Cs}$ の值が高い領域で回路を設計 することは避けるべきであることがわかる.

図4は負荷を含めたインバータ回路の直流電源側 から見た力率をZCS動作領域内に表している. 力 率が高いほど有効電力が増え, 実回路上では効率 向上にもつながる。これを考虑すると図より $\mathrm{Cp} / \mathrm{Cs} \leqq 0.3, \mathrm{Cd} / \mathrm{Cs} \leqq 0.02$ となる点で回路設計を する方がよい.

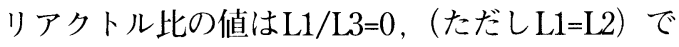
ない限り, 理論上（数值解析上）インバータ回路 のZCS動作の可否に影響を与えるものではない。し かし，島尻らの報告(10)にあるように，リアクトル 比の值が大きくなるほどスイッチのON電流上昇率 が小さくなることがわかっており，実回路上では 安定したZCS動作が可能となる。 また, 図5に示す ようにリアクトル比が大きいほど，インバータ部 のインピーダンスが大きくなり，負荷からインバ 一夕部を通して直流電源側へ回生される電力が小 さくなる。結果, 皮相電力に占める有効電力の割 合が増えるため，わずかに力率が向上する傾向に ある。したがってL1/L3の值を大きく，つまりL1， L2を大きくする方が良いことになるが，回路素子 の大型化や，スイッチに加わる電圧のピーク值が 高くなるといった問題もある。こうしたトレードオフ 


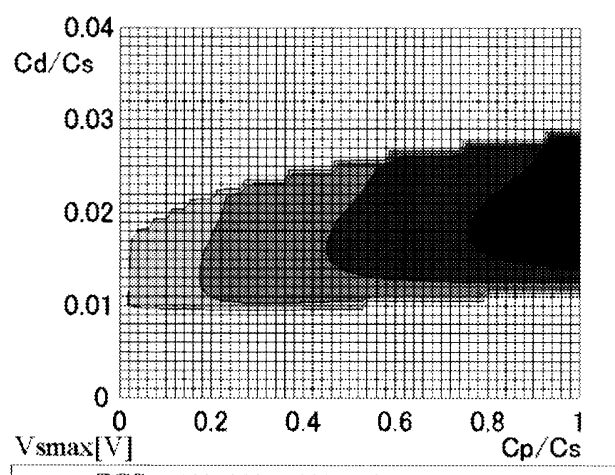

Inon-ZCS $\triangle 100-200=200-300=300-400=400-500$

図6 スイッチ電流最大値

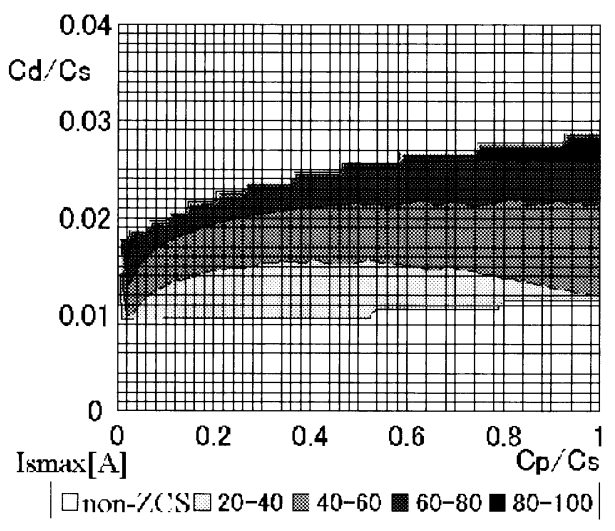

図7 スイッチ電流最大值

の関係を考慮に入れた上でリアクトル比の值を決め ることが重要であり,ここではスイッチング素子のZCS ターンオンを実現できる程度の值とし, 回路の小型化 を意識して $\mathrm{L} 1 / \mathrm{L} 3=\mathrm{L} 2 / \mathrm{L} 3=0.2$ とした。

\section{5 スイッチング素子ストレスの軽減困} 6 と図7で等高線によって描かれているパラメータ は電力を $\mathrm{Po}=750[\mathrm{~W}]$ 出力させる場合にスイッチに 加わる電压の最大值および電流の最大值（Vsmax， Ismax）を示している．大きい定格のスイッチング 素子を利用すれば回路設計は容易になるが，コス ト増となるため，スイッチに流れる電流や電圧を 小さくして，小容量スイッチの利用を可能にする ことが望ましい。そこで電圧最大值および電流最 大值をスイッチに加わるストレスとしてとらえ， これをできるだけ抑制するよう回路設計を行うこ とも重要である。図6から $\mathrm{Cp} / \mathrm{Cs}$ が 0.3 以下, 図7か ら Cd/Csが 0.015 以下であるときにそれぞれのスイ ッチングストレスを軽減できることがわかる，以

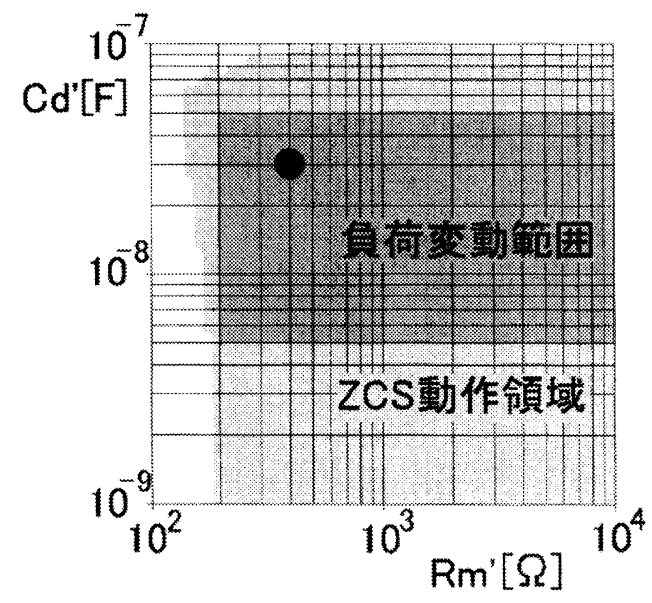

図8 ZCS 動作領域

\begin{tabular}{|c|c|c|}
\hline 璜貝 & 位 & 蛊 \\
\hline 密案 $015^{\circ} \mathrm{C}$ & $\mathrm{g} / \mathrm{cm} 3$ & 0.8655 \\
\hline セ㚈指数 (新JIS式) & & 46.2 \\
\hline F|火点 (PM式) & $\mathrm{c}$ & 74.9 \\
\hline 政数度 $650^{\circ} \mathrm{C}$ & $\mathrm{mm} 2 / \mathrm{s}[\mathrm{cSt}]$ & 2.77 \\
\hline 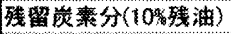 & 器 $\%$ & 0.52 \\
\hline 戻分 & 墭\% & $0.005(-)$ \\
\hline 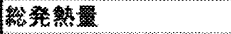 & $\mathrm{cal} / \mathrm{g}$ & 10780 \\
\hline 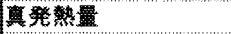 & $\mathrm{cal} / \mathrm{g}$ & 10120 \\
\hline 砝篮分 & 眩 $\%$ & 0.61 \\
\hline 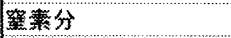 & 留 \% & 0.019 \\
\hline 泉分 & 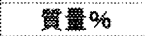 & $0.05(-)$ \\
\hline
\end{tabular}

表2 A重油成分表

上の考察からインバータ回路の設計点を $\mathrm{Cp} / \mathrm{Cs}=0.225, \mathrm{Cd} / \mathrm{Cs}=0.011$ 付近にとることとした.

2. 6 共振点近傍でのインバータ ZCS動作 領域内に回路の設計点を取ることで定常運転時に はインバータ回路のZCS動作が可能になり, 効率 よくかつ安全に運転することができる，超音波振 動子系には固有の機械的共振周波数 $\mathrm{fr}$ があり，こ れとインバータの出力周波数 foが完全に一致した ときにのみ超音波ホモジナイザの「共振状態」を 得られ，このとき超音波ホモジナイザの出力が最 大值となる。しかし fr と foに数 $[\mathrm{Hz}]$ でも差が生じた 場合，振動子系の等価回路定数は大きく変化し， 超音波ホモジナイザの「共振状態」をはずれて高 出力を得にくくなる。またこれに伴う等価回路定 数 $\left(\mathrm{Rm}\right.$ ', $\left.\mathrm{Cd} \mathrm{d}^{\prime}\right)$ の急激で大きな変化によりインバ 一タ回路のZCS動作が困難になる恐れさえある。こ のことから何らかの原因で超音波ホモジナイザの 振動子が「共振状態」からはずれても，またそう 


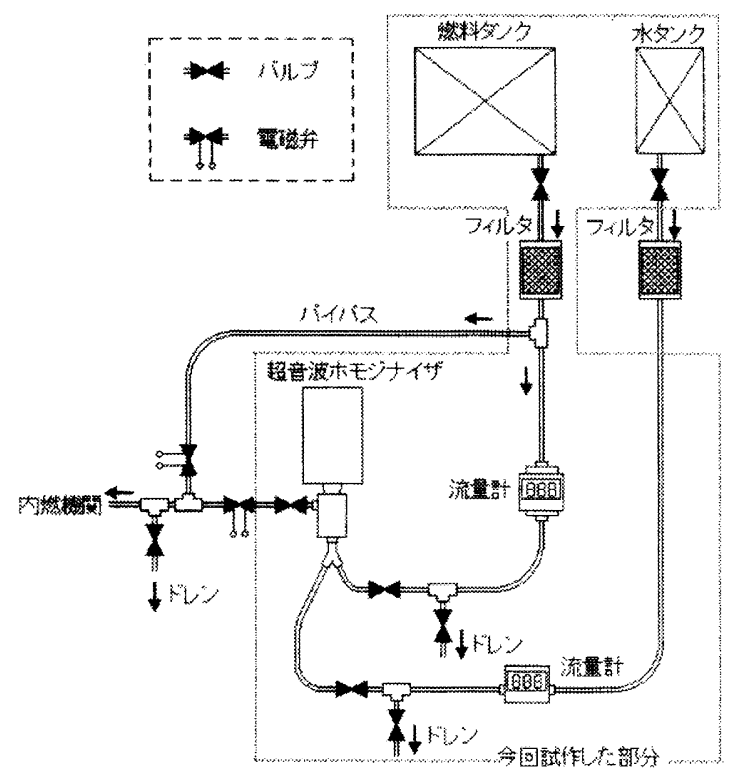

図9実験装置概略

なりつつある過渡状態においてもインバータ回路 のZCS動作が保証されなければならない。超音波 ホモジナイザの振動子が「共振状態」からはずれ るとき, Cd'の変動範囲はおおよそ数 $[\mathrm{nF}] \sim 50[\mathrm{nF}]$ の範囲であり, Rm'のそれは $200[\Omega]$ 数 $[\mathrm{k} \Omega]$ であ る。そこでこれら全ての範囲でZCS動作が保証さ れるかどうかを数值解析により検証した. 図8は Cd'と負荷 Rm'の大きさの変化をそれぞれ縦軸横 軸にとったときのZCS動作領域を示している. 図 中の点は超音波ホモジナイザの共振動作ができ， インバータの安定運転が可能となる設計点である. 図からも明らかなように, 等価回路定数の変動範 囲よりも広い範囲でインバータ回路のZCS動作が

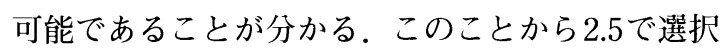
した回路パラメータの值をインバータ回路に採用 したとき, 超音波ホモジナイザが「共振状態」か らはずれてもインバータの安定運転が実現できる ことがわかる.

\section{3. 実験装置}

3. 1 実験装置概要乳化燃料を用いた各種 研究の多くは例えば(11)(12) 乳化処理装置を燃料油タン クとディーゼルエンジンとの間に敷設している。 本実験装置もこれに準じた形で, 燃料油系統内に

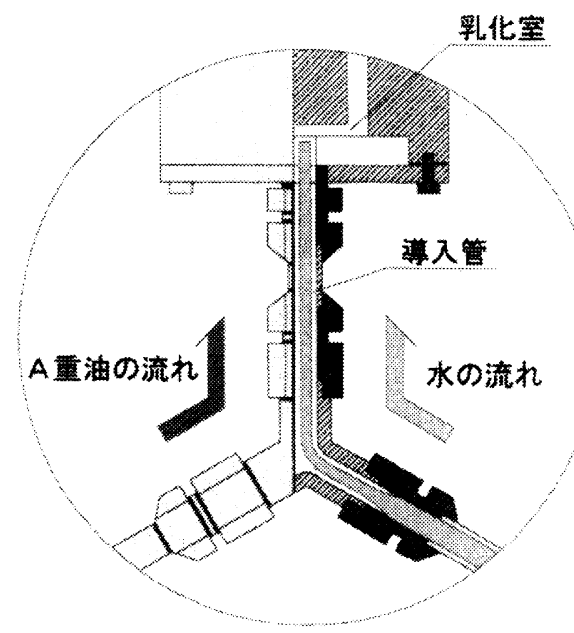

図10 乳化室入り口詳細

超音波ホモジナイザを設置し，インラインで然料 油と水の連続分散乳化処理が可能である。その概 略を罒9に示す。燃料タンクおよび水タンクのへッ ドは一定に保っている。流量の調節および燃料油 への水添加量の調整は超音波ホモジナイザ入口の バルブで行った。

3. 2 超音波ホモジナイザ実験で用いた超 音波ホモジナイザ(USH-1200Z20S, 超音波工業(株) 製) は以前に報告 (2)した通りであるが, 乳化室に燃 料油と水が同時に連続的に流れ込むよう，燃料油 系統と清水系統を二重管構造としている（図10). これにより従来, 超音波ホモジナイザによる処理 の前に水と燃料油の予備覮挥を必要としていたが, そうした前処理が不要になった。

3. 3 供試燃料油供試燃料油には表 2 に示 す市販のA重油を用いた。また，A重油の温度およ び水の温度は室温 $\left(15 \sim 20^{\circ} \mathrm{C}\right)$ とし, 乳化後も室 温にて保存し，その分離状況を観察した。

\section{4. 実験}

2章で述べたZCS高周波インバータを用いてA重 油と水の乳化燃料を生成する実験を行った.

4. 1 評価法実験の条件として, 超音波ホ モジナイザの乳化室に流入する A 重油の流量を

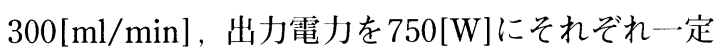




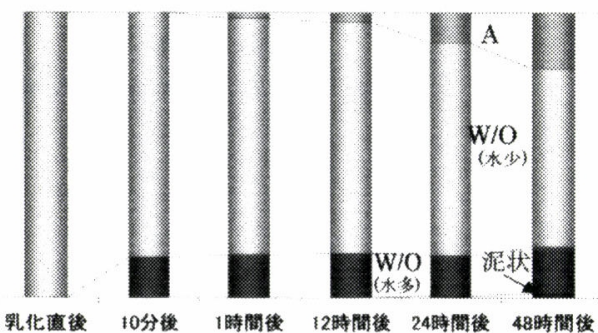

(a) 水潦加慗10\%

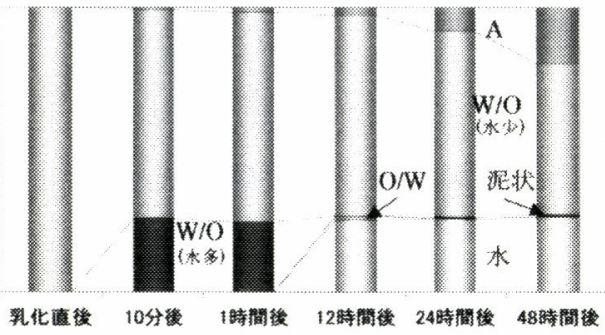

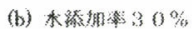

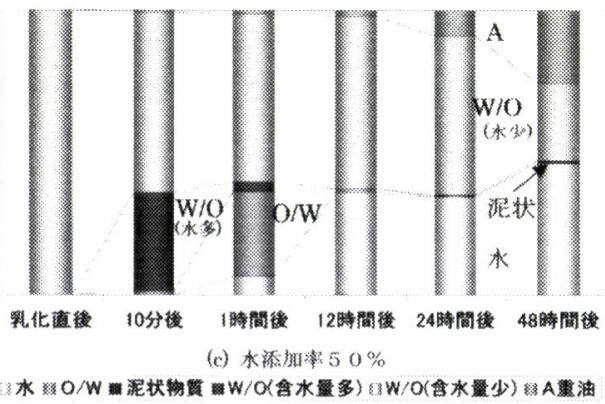

図11 水乳化燃料の分離（乳化剤無し）

とし，添加する水の量を $10 \%(30[\mathrm{ml} / \mathrm{min}]) ， 30 \%$, $50 \%$ と変化させた。また，乳化剤をA重油に対して $0.2 \%$ 添加しての実験も行った。 $\mathrm{O} / \mathrm{W}$ 乳化燃料と $\mathrm{W} / \mathrm{O}$ 乳化燃料との違いは電気導通試験により行っ た。また，O/W乳化燃料と水との区別については 判断が難しいが, 油膜で覆われた乳白色の水泡の 中の濁りが透明になりだす時点で $\mathrm{O} / \mathrm{W}$ 乳化燃料で はなく水であると判断した。

4. 2 乳化実験結果罒11(a)〜 (c) は乳化燃 料の静的安定性について調查するため, 乳化処理 直後から 48 時間後までの乳化燃料の時間変化を図 式化したものである，乳化処理後，しばらくする と上部に透明感のある油膜ができ，その下に重油 成分を多く含んだ茶色のW/O乳化燃料，さらにそ の下に水分を多く含んだクリーム色のW/O乳化燃 料が形成され，一番下に表面を薄い油膜で覆われ た水泡（乳白色）が沈殿した（図12）。A重油に含

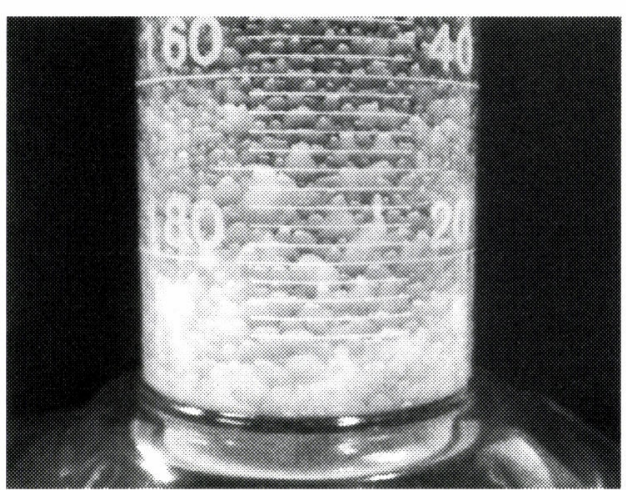

図12 水乳化燃料の分離状況

表3 乳化剤の性状

\begin{tabular}{|c|c|c|}
\hline 項目 & $\mathrm{N}-80$ & $\mathrm{~N}-3-80$ \\
\hline 組成 & ソルビタンステアレート & ソルビタントリオレエート \\
\hline 外観 $\left(20^{\circ} \mathrm{C}\right)$ & 液状 & 液状 \\
\hline 水分(\%)以下 & 1. 0 & 1. 0 \\
\hline 比重 & $0.980 \sim 1.000$ & $0.940 \sim 0.960$ \\
\hline HLB価 & 6. 4 & 3. 4 \\
\hline
\end{tabular}

まれる成分の一部が水に溶け込むため, 分離した $\mathrm{A}$ 重油の色は乳化前と比較して若干薄くなるのが観 察された。中山らの報告 ${ }^{(13)}$ では水と $\mathrm{A}$ 重油が分離 した際に「藻状のもの（外表面を薄い油膜で覆わ れた水泡)」が涊められたとあるが, 超音波ホモジ ナイザを用いた本実験に打いては乳化处理168時間 後の観察に扎いてもそのようなものは確認されな かった。しかし, 水添加率が $10 \%$ の場合, 泥状の (やや黄色味を帯びた) W/O乳化燃料が形成され るのが観察された。 これは径が $0.1 〜 0.5[\mathrm{~mm}]$ ほど の細かい水の粒子がA重油中に均一に分散している 状態で，外観は細かな砂粒状である。また，168時 間後の観察でも粒子同士が結合したり潰れたりす ることなくW/O型を保っていた。しかし，これを 手のひらに取ってすりつぶすと乳白色の $\mathrm{O} / \mathrm{W}$ 型に なるのが観察された。この泥状のW/O乳化燃料は 比較的粘度が高いため, 中山らが「藻状のもの」 について指摘しているのと同様にフィルタや燃料 噴射ノズルなどの目詰まりを打こす恐れがあるた 


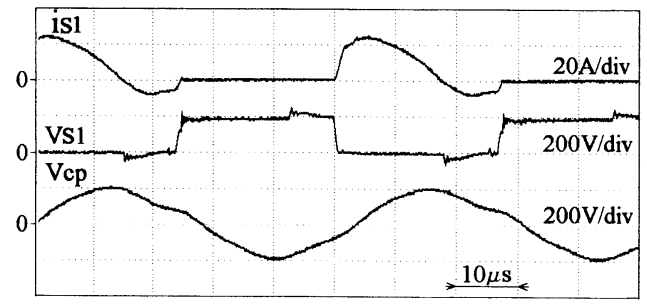

（a）実験波形

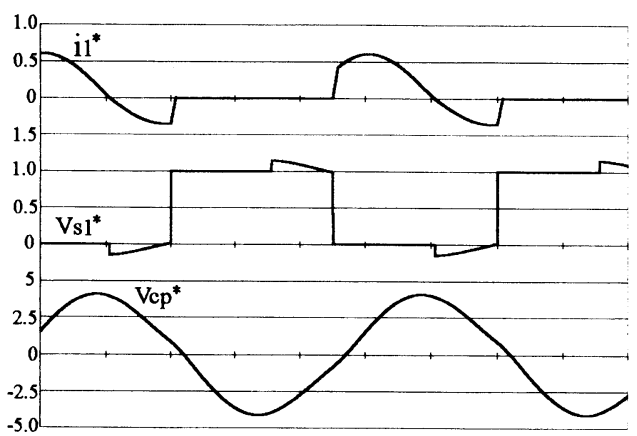

（b）無次元化理論波形

\section{図13各部動作波形}

め, 注意する必要があろう。

4. 3 添加剤を用いた乳化実験 乳化燃料の 安定性向上のため, 乳化剂 (表3)を利用した実験に ついても行った。乳化剂はHLB価が 3.4 と6.4のも の（N-80，N-3-80，日本乳化剂株式会社製）を2:1 の割合で混ぜ合わせ，これをA重油に対し $0.3 \mathrm{Vol} \%$ 溶かし込んだ上で乳化処理した，乳化剂を添加し ない場合と比べ，明らかに水エマルジョン燃料の 安定性が増しているのが確認された。表4にも示す とおり，水分比が高いものほど水の分離が速かっ たが，これは水添加率が増加することにより相詨 的に乳化剂の添加率が下がったことと，超音波ホ モジナイザでの単位流量あたりの処理出力が下が ったことに起因すると考えられる.

\section{4 乳化実験考察 強力超音波振動を用い} ることにより乳化剤無しで安定な水乳化燃料を得 るための実験は，結果として水添加率にかかわら ず数分で分離してしまうことがわかった。また分 離の仕方は，A重油成分の多いW/O と水分が多い $\mathrm{W} / \mathrm{O}$ に分離した後, 水添加率の多いものでは水分 比に応じた量の白濁した $\mathrm{O} / \mathrm{W} か ゙$ 沈殿した。乳化剤 を添加した場合では，添加量が微量でありながら 安定した乳化燃料を生成することができた。しか

\begin{tabular}{|c|c|c|c|c|c|}
\hline \multirow{2}{*}{\multicolumn{2}{|c|}{ 添加率 }} & \multicolumn{4}{|c|}{ 乳化処理後の経過時間 } \\
\hline & & \multirow{2}{*}{$\begin{array}{c}\text { 5分後 } \\
0\end{array}$} & \multirow{2}{*}{$\frac{10 \text { 分後 }}{\times}$} & \multirow{2}{*}{$\begin{array}{c}30 \text { 分後 } \\
\times\end{array}$} & \multirow{2}{*}{$\frac{1 \text { 時間後 }}{x}$} \\
\hline 乳 & $10 \%$ & & & & \\
\hline 化 & $20 \%$ & $x$ & $x$ & $x$ & $x$ \\
\hline 剂 & $30 \%$ & $x$ & $x$ & $x$ & $x$ \\
\hline 無 & $40 \%$ & $x$ & $x$ & $x$ & $x$ \\
\hline ᄂ & $50 \%$ & $x$ & $x$ & $x$ & $x$ \\
\hline 乳 & $10 \%$ & $\mathrm{O}$ & 0 & $\mathrm{O}$ & $\mathrm{O}$ \\
\hline 化 & $20 \%$ & 0 & 0 & 0 & 0 \\
\hline 棛 & $30 \%$ & 0 & 0 & 0 & $x$ \\
\hline 有 & $40 \%$ & 0 & 0 & $x$ & $x$ \\
\hline り & $50 \%$ & 0 & 0 & $x$ & $x$ \\
\hline
\end{tabular}

表4 乳化処理後の状態

し水添加率が多い場合は，30分程度でわずかに水 の析出が見られるなど, 分離が早いため乳化处理 から燃焼まで時間のかかるシステムでは注意を要 する．いずれにしても乳化処理後短時間のうちに 燃焼できる場合, 強力超音波による乳化处理を行 うことで乳化浏の添加率を少なくできると考えら れる。

4. 5 高周波電源各部動作波形 実験に用い た新 2 石型SEPP - ZCS高周波インバータ回路の理 論波形を図13に示す。（a）は実験時の各部動作波形 を，（b）は数值解析による無次元化された各部動作 波形をそれぞれ表している。スイッチ電流扰よび ダイオード電流の合成波形i1はターンオン時には 電流值がゼロから始まっており, ダイオードター ンオフ時に電流值がある傾きを持ってゼロになる ため, ZCSターンオンとZCSターンオフを同時に 実現している。また，ダイオードのリカバリー電 流の発生やサージ電压の発生なども抑制されてい る. 出力電圧波形 $\mathrm{V} c \mathrm{p}$ 歪みはある程度除去できて

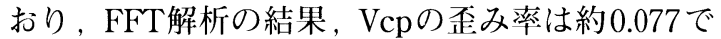
あった。回路設計は $700 〜 800[\mathrm{~W}]$ 程度出力するこ とを目処に行っているが, 等価回路定数が変化し てより厳しい運転条件となる $1000[\mathrm{~W}]$ 出力の場合 においても，問題なく動作することができた.

\section{5. あとがき}

超音波ホモジナイザ用の高周波インバータの開 発とその回路設計を行った.SEPP型回路としたこ とで，回路の簡素化，ローコスト化を可能にした。 高周波インバータのZCS動作を実現すると同時に， 
高効率動作を得るための回路パラメータの最適化 が重要課題であるが，本研究では出力電力の歪み 率の低減とスイッチング素子ストレスの軽減に着 目することで，回路パラメータの選択を容易にす ることができた。また広い負荷の変動範囲を考慮 に入れた回路設計によりインバータ回路の安定し たソフトスイッチング動作を実現可能とした。こ の高周波インバータを電源として用いた超音波ホ モジナイザの強力超音波振動により，乳化剂無し で，または極微量の乳化剤で水乳化燃料を生成す る実験を行った。強力超音波による乳化処理方式 は通常の機械的乳化処理に比べ水粒子が細かく均 一に分散乳化するとされているが(3)，結果的には 燃料油が水と比重差の少ないA重油である場合, 乳 化剤無しでは水乳化燃料を安定な状態に保つこと が困難であった。したがって水乳化燃料の安定化 には乳化㓮が必要であると考えられる。しかし山 本らの報告 ${ }^{(11)} の$ 中にもあるように，燃料噴射ポン プからの漏油の処理について考慮に入れると, 乳 化剂を添加していない方が油水分離器等で燃料油 と水を分離しやすくなり，後処理作業が繁雑にな らなくなるという可能性も出てくる。これらのこ

付

$$
\begin{aligned}
& \mathrm{S}_{1} \text { 単流モード } \\
& \frac{\mathrm{di}_{1} *}{\mathrm{dz}}=\frac{2 \pi}{\mu}\left(1-\mathrm{vcs}^{*}-\mathrm{vcp}^{*}\right) \\
& \frac{\mathrm{di}_{2} *}{\mathrm{dz}}=0 \\
& \frac{\mathrm{di}_{3}^{*}}{\mathrm{dz}}=\frac{2 \pi}{\mu}\left(1-\mathrm{vcs}^{*}-\mathrm{vcp}^{*}\right) \\
& \frac{\mathrm{dvcs}^{*}}{\mathrm{dz}}=\frac{2 \pi}{\mu} \mathrm{i}_{3}^{*} \\
& \frac{\mathrm{dvcp}^{*}}{\mathrm{dz}}=\frac{2 \pi}{\mu} \cdot \frac{\mathrm{n}^{2}}{\mathrm{n}^{2} \alpha+\beta}\left(\mathrm{i}_{3}^{*}-\frac{\mathrm{vcp}^{*}}{\lambda}\right) \quad \text {--付 } 1
\end{aligned}
$$$$
\text { D } 1 \text { 単流モード }
$$$$
\frac{\mathrm{di}_{1} *}{\mathrm{dz}}=\frac{2 \pi}{\mu} \cdot \frac{1}{\gamma+1}\left(1-\mathrm{vcs}^{*}-\mathrm{vcp}^{*}\right)
$$$$
\frac{\mathrm{di}_{2}^{*}}{\mathrm{dz}}=0
$$$$
\frac{\mathrm{di}_{3} *}{\mathrm{dz}}=\frac{2 \pi}{\mu} \cdot \frac{1}{\gamma+1}\left(1-\mathrm{vcs}^{*}-\mathrm{vcp}^{*}\right)
$$$$
\frac{\mathrm{dvcs}^{*}}{\mathrm{dz}}=\frac{2 \pi}{\mu} \mathrm{i}_{3} *
$$$$
\frac{\mathrm{dvcp} *}{\mathrm{dz}}=\frac{2 \pi}{\mu} \cdot \frac{\mathrm{n}^{2}}{\mathrm{n}^{2} \alpha+\beta}\left(\mathrm{i}_{3}{ }^{*}-\frac{\mathrm{vcp}^{*}}{\lambda}\right) \quad \text {--付 } 2
$$

とから乳化剂を用いずに水乳化燃料を生成する場 合, 乳化処理後ごく短時間の内に水乳化燃料が燃 料噴射ポンプに到達できるように超音波ホモジナ イザ等の乳化処理装置の設置場所を工夫する必要 があろう。

\section{文献}

（1）畑中ほか 2名, 舶機誌, Vol.29, No.11（1994）, 788797

（2）畑中・山神，舶機誌，Vol.27，No.8（1993），598

(3) “乳化燃料による排気浄化に関する調査研究委員会報 告書”, 日本舶用機関学会, (平成 9 年), 22-33及び20-21

（4）畑中ほか 2 名，舶機講51回前刷，(平5-5)

（5）孫・畑中，舶機講53问前刷，(平6-5)，120-123

（6）木船ほか 2 名，舶機講60回前刷，(平10-5)，123-128

(7) 木船ほ力 4 名, 電気学会講演論文集 $[4], 1412$

（8）趙ほか2 名, 舶機講64回前刷，(平11-5)，101-104

（9）（社）日本電子機械工業会編，超音波工学

(10) S.Shimaji, Y.Hatanaka, Proc of ICPE' 98, (1998)

（11）山本 ·神田，舶機誌，Vol.35, No.1 (2000)，38-45

（12）薛·長谷川，舶機誌, Vol.35, No.4 (2000), 274-279

（13）中山ほか2名, 舶機誌, Vol.32, No.3 (1997)，243251

\section{録}

$$
\begin{aligned}
& \text { Dp1・S2重流モード } \\
& \frac{\mathrm{di}_{1} *}{\mathrm{dz}}=\frac{2 \pi}{\mu \gamma} \\
& \frac{\mathrm{di}_{2}^{*}}{\mathrm{dz}}=\frac{2 \pi}{\mu}\left(\frac{1}{\gamma}+\mathrm{vcp}^{*}+\mathrm{vcs}^{*}\right) \\
& \frac{\mathrm{di}_{3}^{*}}{\mathrm{dz}}=-\frac{2 \pi}{\mu}\left(\mathrm{vcp}^{*}+\mathrm{vcs}^{*}\right) \\
& \frac{\mathrm{dvcs}^{*}}{\mathrm{dz}}=\frac{2 \pi}{\mu} \mathrm{i}_{3} * \\
& \frac{\mathrm{dvcp}^{*}}{\mathrm{dz}}=\frac{2 \pi}{\mu} \cdot \frac{\mathrm{n}^{2}}{\mathrm{n}^{2} \alpha+\beta}\left(\mathrm{i}_{3} 3^{*}-\frac{\mathrm{vcp}^{*}}{\lambda}\right) \quad \text { - - 付 } 3 \\
& \text { Dp2単流モード } \\
& \frac{\mathrm{di}_{1}{ }^{*}}{\mathrm{dz}}=0 \\
& \frac{\mathrm{di}_{2}^{*}}{\mathrm{dz}}=\frac{2 \pi}{\mu} \cdot \frac{1}{\gamma-1}\left(\mathrm{vcs}^{*}+\mathrm{vcp}^{*}\right) \\
& \frac{\mathrm{di}_{3}{ }^{*}}{\mathrm{dz}}=-\frac{2 \pi}{\mu} \cdot \frac{1}{\gamma-1}\left(\mathrm{vcs}^{*}+\mathrm{vcp}^{*}\right) \\
& \frac{\mathrm{dvcs}^{*}}{\mathrm{dz}}=\frac{2 \pi}{\mu} \mathrm{i}_{3}{ }^{*} \\
& \frac{\mathrm{dvcp} *}{\mathrm{dz}}=\frac{2 \pi}{\mu} \cdot \frac{\mathrm{n}^{2}}{\mathrm{n}^{2} \alpha+\beta}\left(\mathrm{i}_{3}{ }^{*}-\frac{\mathrm{vcp}^{*}}{\lambda}\right) \quad \text {--付 } 5
\end{aligned}
$$


S2単流モード

$\frac{\mathrm{di}_{1}{ }^{*}}{\mathrm{dz}}=0$

$\frac{\mathrm{di}_{2}^{*}}{\mathrm{dz}}=\frac{2 \pi}{\mu}\left(\mathrm{vcs}^{*}+\mathrm{vcp}^{*}\right)$

$\frac{\mathrm{di}_{3}^{*}}{\mathrm{dz}}=-\frac{2 \pi}{\mu}\left(\mathrm{vcs}^{*}+\mathrm{vcp} *\right.$

$\frac{\mathrm{dvcs}^{*}}{\mathrm{dz}}=\frac{2 \pi}{\mu} \mathrm{i}_{3}{ }^{*}$

$\frac{\mathrm{dvcp}^{*}}{\mathrm{dz}}=\frac{2 \pi}{\mu} \cdot \frac{\mathrm{n}^{2}}{\mathrm{n}^{2} \alpha+\beta}\left(\mathrm{i}_{3}{ }^{*}-\frac{\mathrm{vcp}^{*}}{\lambda}\right) \quad---$ 付 4

$\mathrm{Dp} 2 \cdot \mathrm{S} 1$ 重流モード

$\frac{\mathrm{di}_{1}{ }^{*}}{\mathrm{dz}}=\frac{2 \pi}{\mu}\left(\frac{1}{\gamma}+1-\mathrm{vcs}^{*}-\mathrm{vcp}^{*}\right)$

$\frac{\mathrm{di}_{2} *}{\mathrm{dz}}=\frac{2 \pi}{\mu \gamma}$

$\frac{\mathrm{di}_{3}{ }^{*}}{\mathrm{dz}}=\frac{2 \pi}{\mu}\left(1-\mathrm{vcs}^{*}-\mathrm{vcp}^{*}\right)$

$\frac{\mathrm{dvcs}^{*}}{\mathrm{dz}}=\frac{2 \pi}{\mu} \mathrm{i}_{3} *$

$\frac{\mathrm{dvcp}^{*}}{\mathrm{dz}}=\frac{2 \pi}{\mu} \cdot \frac{\mathrm{n}^{2}}{\mathrm{n}^{2} \alpha+\beta}\left(\mathrm{i}^{*}-\frac{\mathrm{vcp}^{*}}{\lambda}\right) \quad$--付 6
OFFモード

$\frac{\mathrm{di}_{1} *}{\mathrm{~d} z}=0$

$\frac{\mathrm{di}_{2} *}{\mathrm{dz}}=0$

$\frac{\mathrm{di}_{3} *}{\mathrm{~d} z}=0$

$\frac{\mathrm{dvcs} *}{\mathrm{~d} z}=0$

$\frac{\mathrm{dvcp} *}{\mathrm{~d} z}=-\frac{2 \pi}{\mu} \cdot \frac{\mathrm{n}^{2}}{\mathrm{n}^{2} \alpha+\beta} \cdot \frac{\mathrm{vcp} *}{\lambda} \quad-$ - 付 7 